\title{
Paleomagnetism of Upper Triassic continental sedimentary rocks from the Dan River-Danville rift basin (eastern North America)
}

\author{
Dennis V. Kent* \\ Paul E. Olsen \\ Lamont-Doherty Earth Observatory of Columbia University, Palisades, New York 10964
}

\section{ABSTRACT}

A magnetic polarity stratigraphy and a corresponding paleomagnetic pole position are reported from 113 sampling sites representing $3000 \mathrm{~m}$ of Upper Triassic continental sedimentary rocks that crop out in the Dan River-Danville basin of North Carolina and Virginia. Characteristic magnetizations isolated by thermal demagnetization for either the hematite-bearing red siltstones or the interbedded magnetite-bearing gray to black mudstones of the Leakesville Formation are indistinguishable in mean direction and pass reversal tests. The magnetic polarity sequence consists of 11 magnetozones that vary from $\approx 100 \mathrm{~m}$ to $800 \mathrm{~m}$ in thickness and can be uniquely correlated within biostratigraphic constraints to magnetochrons E9n to E14n of the Newark geomagnetic polarity time scale. According to this correlation, the sampled section is the age equivalent of the uppermost Stockton, the entire Lockatong, and the lowermost Passaic formations of the Newark basin, and represents $\approx 7.5 \mathrm{~m}$.y. of deposition. The late Carnian Dan River-Danville paleopole is located at $55.4^{\circ} \mathrm{N} 100.1^{\circ} \mathrm{E}\left(\mathrm{A}_{95}=1.9^{\circ}\right)$, which is not significantly different from paleopoles reported from essentially coeval rocks in the Newark basin. Considering that the Dan River-Danville and Newark basins are $\approx 600 \mathrm{~km}$ apart, the close agreement of the coeval paleopoles argues strongly for the overall tectonic coherence of these rift basins with respect to each other and, most probably, with respect to cratonic North America. Discordant latest Triassic paleopoles from the southwestern United States, which have tended to be attributed to fast apparent polar wander for North America in the Late Triassic and predict anomalously high paleolatitudes for eastern North America, are best accounted

*E-mail address: dvk@ldgo.columbia.edu for by a large net clockwise rotation of the Colorado Plateau.

\section{INTRODUCTION}

An extensive series of rift basins developed in eastern North America in the Late Triassic and Early Jurassic during the initial rifting of Pangea (Fig. 1). These rifts filled with thousands of meters of continental sedimentary and igneous rocks of the Newark Supergroup (Olsen, 1978; Froelich and Olsen, 1984). The largest of the exposed basins is the Newark basin, where paleomagnetic studies of outcrop sites have outlined a magnetic polarity stratigraphy (McIntosh et al., 1985; Witte and Kent, 1989, 1990; Witte et al., 1991) and have documented an interval of slow apparent polar wander (Kent and Witte, 1993). However, the interpretation of paleopoles from the Newark basin as representative of North America has been challenged because of apparently conflicting paleomagnetic results from the southwestern United States (e.g., Molina-Garza et al., 1995), prompting suggestions that tectonic rotations may have distorted the paleomagnetic record in some of the Newark basins (e.g., Kodama et al., 1994a). A detailed reference section of geomagnetic reversals and Milankovitch cyclic climate change was obtained for the Newark basin from study of more than $6500 \mathrm{~m}$ of core recovered under the Newark Basin Coring Project (Kent et al., 1995; Olsen et al, 1996; Olsen and Kent, 1996). This complete 30 m.y. record provides a framework for making specific comparisons and tests of the stratigraphic and tectonic development of other Newark Supergroup sequences.

This study focuses on the Dan RiverDanville basin, located $600 \mathrm{~km}$ south of the Newark basin (Fig. 1). Our objectives are to develop a magnetostratigraphy for precise temporal correlation to the Newark basin, and to use the corresponding paleomagnetic pole position for assessing the tectonic coherence of the Newark rift basins.

\section{GEOLOGIC SETTING AND SAMPLING}

Of the 20 or so exposed Newark rift basins, the Dan River-Danville basin has an exceptionally large aspect ratio in outcrop, being more than $165 \mathrm{~km}$ long but less than $15 \mathrm{~km}$ wide (Fig. 1, a and b). The basin is bounded on the northwest by the Chatham fault zone, a southeast-dipping normal fault system trending about $\mathrm{N} 30^{\circ} \mathrm{E}$. The sedimentary rocks in the basin dip $20^{\circ}$ to $50^{\circ}$ toward this fault system and generally rest unconformably over basement along most of the southeastern margin of the basin. A dual system of nomenclature has evolved from the mapping by Meyertons (1963) of the Danville basin in Virginia and by Thayer (1970) of the Dan River basin in North Carolina. The sedimentary rocks in the basin are referred to as the Dan River Group (Thayer, 1970) and have a stratigraphic thickness of up to more than $4000 \mathrm{~m}$. The rocks we sampled are partly in Virginia and partly in North Carolina, and to avoid nomenclatural confusion are referred to here as Leakesville Formation (Meyertons, 1963). Late Carnian pollen, spores, and vertebrates have been found in the lower and upper Cow Branch Members of the Leakesville Formation (Robbins and Traverse, 1980; Olsen et al., 1982; Thayer et al., 1982; Olsen and Gore, 1989).

To assemble a continuous stratigraphic sequence, we concentrated paleomagnetic sampling along two overlapping transects of the basin stratigraphy. The Eden section in North Carolina was sampled at 28 sites with generally 3 or more oriented drill-core samples per site in fresh exposures in an unnamed creek bed in the town of Eden (Fig. 1c). The section begins just above cyclic gray to carbonaceous black mudstones of the lower Cow Branch Member and covers $\approx 550 \mathrm{~m}$ of reddish to gray siltstones and sandstones of the unnamed division of the Leakesville Formation to just below a covered interval above which are exposures of the upper Cow Branch Member. The Cascade section, located $\approx 15 \mathrm{~km}$ from the Eden section in North Carolina and Vir- 


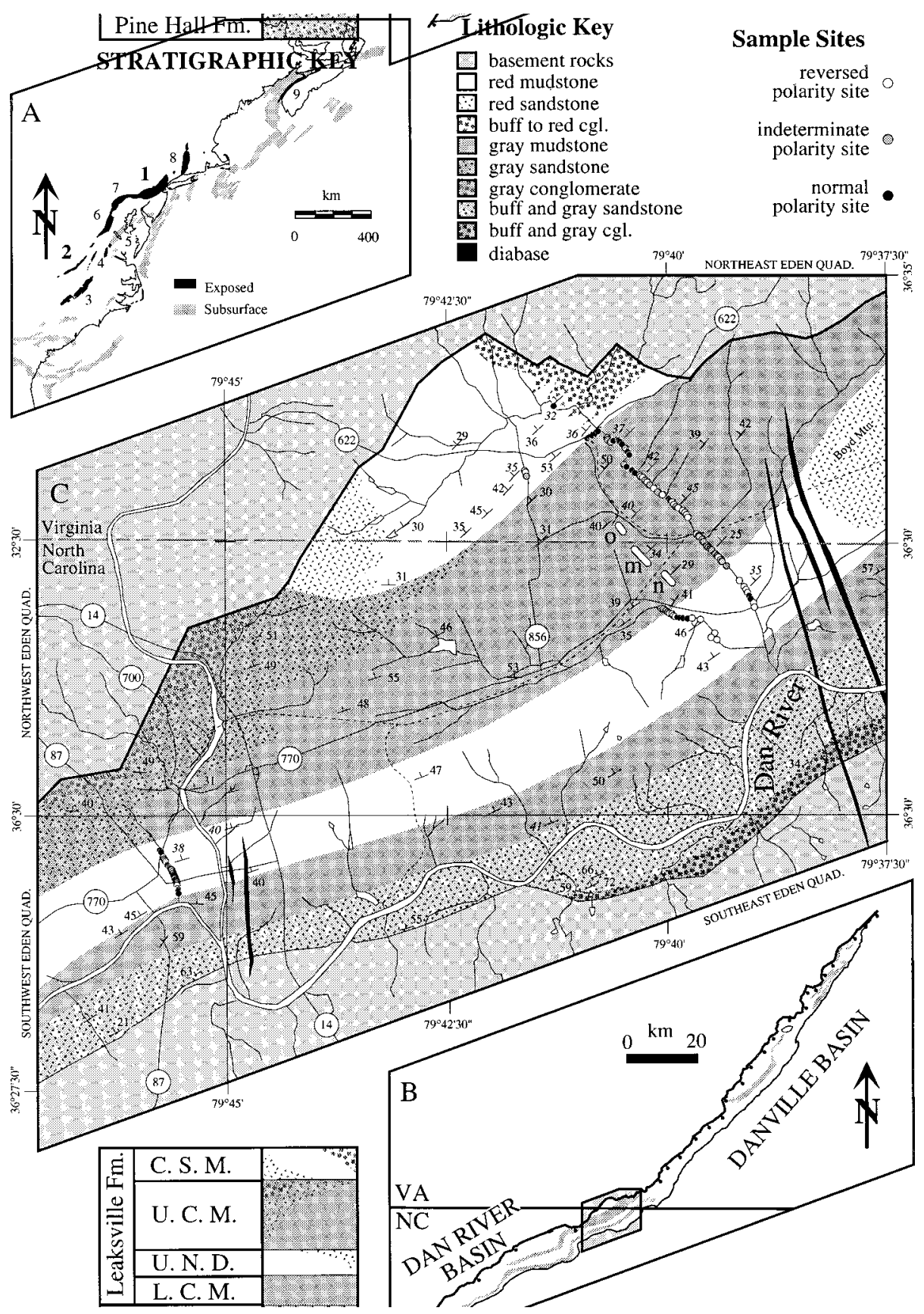

Figure 1. (A) Newark Supergroup basins in eastern North America. 1-Newark, 2-Dan River-Danville, 3-Deep River-Durham, 4-Richmond, 5-Taylorsville, 6-Culpeper, 7Gettysburg, 8-Hartford-Deerfield, 9-Fundy. (B) Geologic sketch map of Dan River-Danville basin. (C) Geologic map, extensively modified from base of Meyertons (1963) and Thayer (1970), of portion of Dan River-Danville basin outlined in B showing paleomagnetic sampling sites in the Cascade section (CS) and the Eden section (ES). Virginia Solite Corporation quarries that were sampled are labeled o (old quarry), m (main quarry), and $\mathbf{n}$ (new quarry). Strikes and dips that we measured are in italics; other strikes and dips are from Meyertons (1963) and Thayer (1970). Subdivisions of Leakesville Formation are abbreviated in stratigraphic key as L.C.M. (lower Cow Branch Member), U.N.D. (unnamed division), U.C.M. (upper Cow Branch Member), and C.S.M. (Cascade Station Member). ginia, was sampled at 137 sites in exposures in the beds of Cascade and Dry Creeks and in the adjacent faces of the New, Main, and Old quarries of the Virginia Solite Corporation (Fig. 1c). This sampled portion of the Leakesville Formation consists of reddish to gray siltstones and sandstones of predominantly lacustrine facies in the unnamed lower 400-m-thick division, followed by an $\approx 1950$-m-thick sequence of cyclic gray to black mudstones of deeper water lacustrine facies of the upper Cow Branch Member, and overlain by at least $400 \mathrm{~m}$ of predominantly reddish sandstones and siltstones with gray to black siltstones and interbedded gray to buff conglomerates of the Cascade Station Member. A total of $\approx 3000 \mathrm{~m}$ of the Dan River Group is represented by 165 sampling sites in the Cascade and Eden sections combined.

\section{PALEOMAGNETIC RESULTS}

The magnetic properties of the rocks sampled in the Cascade and Eden sections are similar to those encountered in the Newark basin sedimentary sequence, especially in the Lockatong Formation. Thermal demagnetization of isothermal remanent magnetization (IRM) suggests that hematite (high coercivity, maximum unblocking of $680{ }^{\circ} \mathrm{C}$; Fig. 2, a and b) is the principal carrier of remanence in the buff to reddish clastic units (collectively termed "red siltstones" hereafter) that occur in the unnamed division and the Cascade Station Member of the Leakesville Formation, whereas magnetite (moderate coercivity, maximum unblocking at of $580{ }^{\circ} \mathrm{C}$; Fig. 2, a and c) and/or some form of ferromagnetic sulfide (e.g., greigite or pyrrhotite, with moderate coercivity and maximum unblocking to only $350{ }^{\circ} \mathrm{C}$; Fig. 2, a and d) are the carriers of remanence in the gray to black mudstones (collectively termed "gray mudstones" hereafter) that are predominant in the upper Cow Branch Member.

The gray mudstones of the upper Cow Branch Member are a generally difficult lithology for paleomagnetic study due to the common presence of sulfides, which do not seem to preserve an ancient magnetization in these rocks. For example, the success rate of obtaining characteristic magnetizations was only $57 \%$, compared to $86 \%$ for hematite-bearing reddish rocks in the Newark basin study (Kent et al., 1995). In the Cascade section, we also encountered anomalously high intensities of natural remanent magnetization (NRM) in a number of gray mudstone sites from the creek beds. Samples collected in the quarries have NRM intensities that range up to $\approx 10 \mathrm{~mA} / \mathrm{m}$ (mean, $\approx 1 \mathrm{~mA} / \mathrm{m}$ ), whereas some samples from the corresponding interval sampled in Cascade Creek have NRM intensities that range up to $10000 \mathrm{~mA} / \mathrm{m}$, although the magnetic suscepti- 
a)

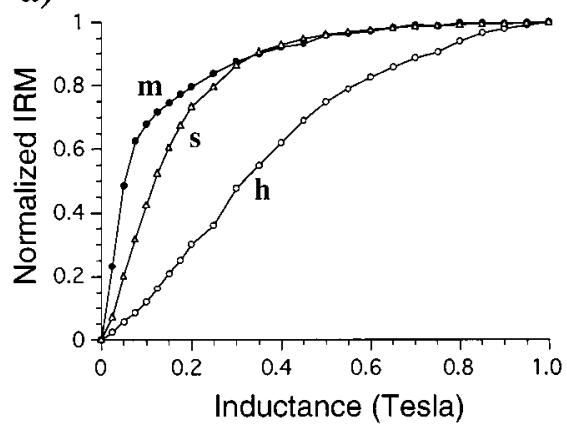

c)

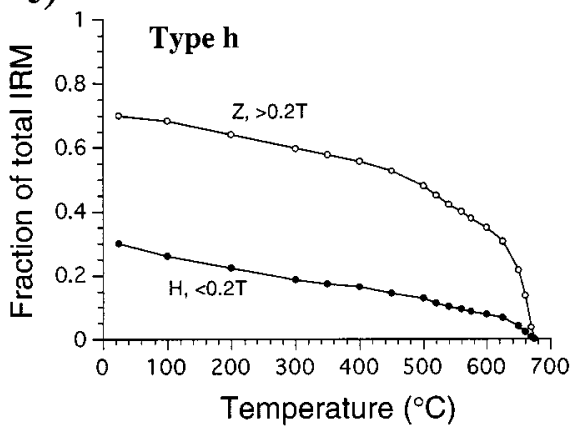

b)

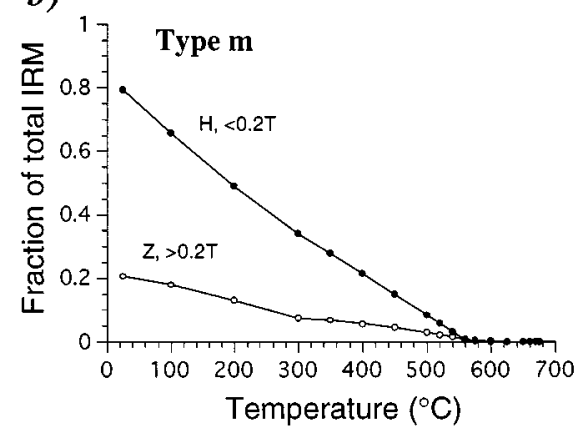

d)

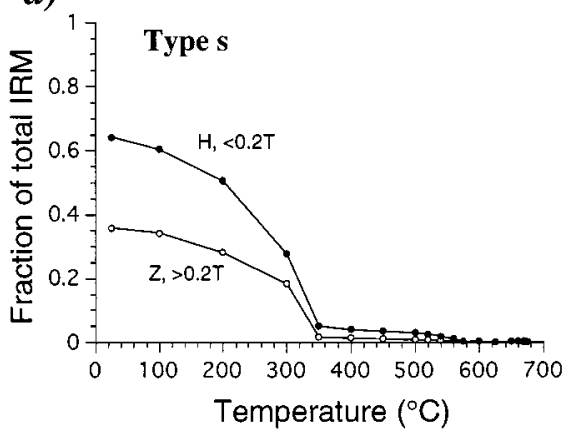

Figure 2. Acquisition (a) and thermal demagnetization (b, c, d) of isothermal remanent magnetization (IRM) according to method of Lowrie (1990) of representative samples, the magnetic mineralogy of which is dominated by $h$ (hematite), $m$ (magnetite), and s (sulfide with some magnetite). IRM orthogonal components in $b, c$, and $d$ are for coercivities from $0.2 \mathrm{~T}$ to $1.0 \mathrm{~T}$ along the $\mathrm{Z}$ axis and less than $0.2 \mathrm{~T}$ along the $\mathrm{H}$ axis.

bilities are very similar for the two populations. We attribute the anomalously high NRM intensities to lightning strikes that preferentially affected the gray mudstones in the creek beds; these rocks may be prone to effects of lightning because of their lower coercivity magnetic minerals and immersion in water, which provides a good path for electric currents in an area of low topographic relief. A total of 11 Cascade section sites that included samples with ratios of NRM intensity to susceptibility greater than 1 are suspected to have undergone remagnetization by lightning and have been rejected on this basis alone.

Thermal demagnetization was used to resolve components of NRM. A minimum of 10 demagnetization steps to $575^{\circ} \mathrm{C}$ was scheduled for the gray to black mudstones, or to $675^{\circ} \mathrm{C}$ for the hematite-bearing rocks, using techniques and equipment described by Kent et al. (1995). Vector end-point diagrams illustrating the range of NRM demagnetization behavior are shown in Figure 3.

First removed by $\approx 300{ }^{\circ} \mathrm{C}$ in most samples not affected by lightning is a magnetization (component A) aligned more or less along the present-day field (Fig. 3, a-f). Parenthetically, the gray mudstone samples with anomalously high NRM intensities tend to have univectorial magnetizations of various directions as another signature of lightning effects. More than half (58) of the remaining 91 sites in gray mudstones (i.e., exclusive of those obviously affected by lightning) show evidence for an ancient component of magnetization that is revealed from 300 to $\approx 560{ }^{\circ} \mathrm{C}$. This characteristic $(\mathrm{Cm})$ component has a shallow direction that is either southerly (Fig. 3a) or northerly (Fig. 3b) in different sites. In many of the other gray mudstone sites, there is hardly any consistent magnetization remaining above $300{ }^{\circ} \mathrm{C}$ (Fig. 3d). Alternating field demagnetization was not found to be effective in resolving the characteristic magnetization in any of the rocks (e.g., Fig. 3c).

A dual polarity characteristic (Ch) component can also be resolved in most of the red siltstone sites over the highest part of the unblocking temperature spectrum, typically from 650 to $675^{\circ} \mathrm{C}$ (Fig. 3, e and f). However, between the unblocking ranges of the $\mathrm{A}$ and the $\mathrm{Ch}$ components, many of the red siltstone sites show evidence for another magnetization; this Bh component has a northerly and moderately down direction and is most obvious in but not restricted to sites with a southerly Ch magnetization (e.g., Fig. 3f).
Least-square line fits were used to determine the component directions from the chosen demagnetization intervals, typically $100-300^{\circ} \mathrm{C}$ for component A, $300-600{ }^{\circ} \mathrm{C}$ for component $\mathrm{Bh}$, $350-575{ }^{\circ} \mathrm{C}$ for component $\mathrm{Cm}$, and $650-675^{\circ} \mathrm{C}$ for component $\mathrm{Ch}$. Component estimates with maximum angular deviations (Kirschvink, 1980) greater than $15^{\circ}$ were rejected as poorly defined except in a few cases where a great circle trend was obvious and a stable end point direction was used. Mean directions were calculated using standard Fisher statistics (Table 1).

Component A was isolated in 142 sites representing all the principal rock types and has a mean direction in geographic coordinates of declination (D) $=351.8^{\circ}$, inclination $(\mathrm{I})=54.3$, and $\alpha_{95}=1.8^{\circ}$ (Table 1). The A component lies in the vicinity of the modern field direction $\left(\mathrm{D}=352.5^{\circ}, \mathrm{I}=66.2^{\circ}\right.$ ) and the time-averaged dipole field orientation (D $=0^{\circ}, \mathrm{I}=56^{\circ}$ ), consistent with a relatively recent origin as a viscous magnetization.

Component Bh was isolated in 57 sites and has a direction distinctly shallower than component A in either geographic $\left(\mathrm{D}=8.5^{\circ}, \mathrm{I}=40.4^{\circ}\right.$, and $\left.\alpha_{95}=2.9^{\circ}\right)$ or bedding coordinates $\left(\mathrm{D}=357.3^{\circ}, \mathrm{I}\right.$ $=18.2^{\circ}$, and $\alpha_{95}=3.2^{\circ}$ ) (Fig. 4, $\mathrm{a}$ and $\mathrm{b}$; Table 1 ). The site-mean directions are somewhat but not statistically significantly better grouped in geographic than in bedding coordinates. Its uniform normal polarity, direction, and relatively high unblocking temperatures suggest that component $\mathrm{Bh}$ is an overprint of ancient origin carried by hematite.

Components $\mathrm{Cm}$ (60 sites) and Ch (53 sites) each have a bipolar distribution of directions (Fig. 4, c and d). There is an insignificant difference of only $5.1^{\circ}$ between the bedding tilt corrected means of the $\mathrm{Cm}$ and the $\mathrm{Ch}$ sites (Table 1), suggesting that the magnetite-bearing and hematite-bearing sites belong to the same population of characteristic magnetizations. The mean direction for all 113 sites after inverting to common polarity is $\mathrm{D}=0.3^{\circ}, \mathrm{I}=3.6^{\circ}$, and $\alpha_{95}$ $=2.5^{\circ}$ in bedding coordinates. There is only a slight improvement in grouping with bedding tilt correction due to the relatively small variation in structural attitudes; a fold test is therefore inconclusive as for the other components (Fig. 4, e and f; Table 1). Northerly or normal polarity directions are found in 37 sites (mean $\mathrm{D}=0.5^{\circ}$, I $=6.2^{\circ}$, and $\alpha_{95}=4.4^{\circ}$ ) and southerly or reverse polarity directions in 76 sites (mean $\mathrm{D}=180.1^{\circ}$, $\mathrm{I}=-2.4^{\circ}$, and $\alpha_{95}=3.1^{\circ}$ ). The normal and reverse directions are within $3.8^{\circ}$ of antipodal, providing a positive reversal test (class B; McFadden and McElhinny, 1990) and indicating that the characteristic directions carried by magnetite or hematite are not systematically biased by unremoved overprints. The $\mathrm{Ch}$ and $\mathrm{Cm}$ components thus appear to represent magnetizations acquired 


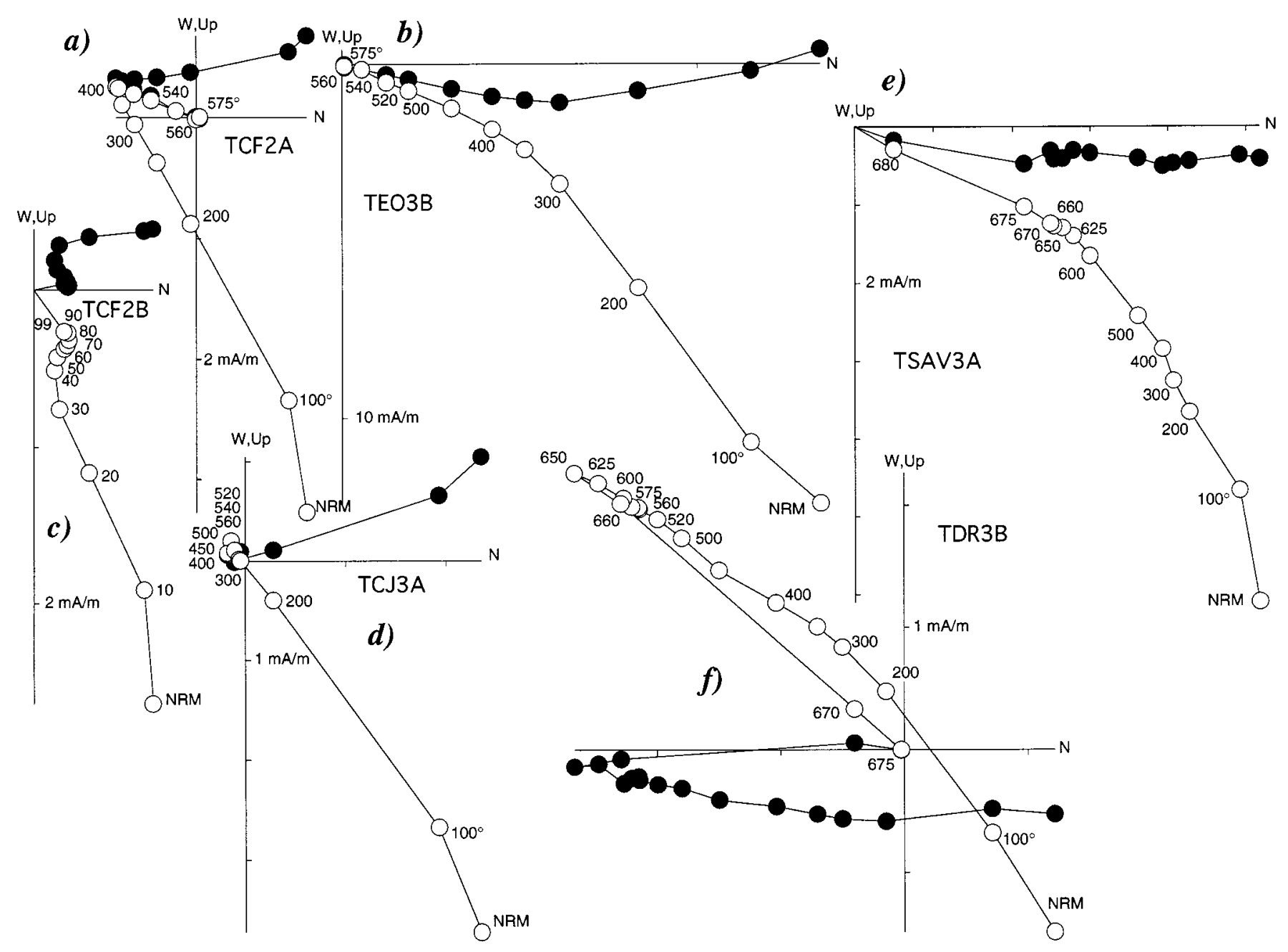

Figure 3. Vector end-point demagnetization diagrams of natural remanent magnetization of representative samples from the Dan River-Danville basin sections, with open and closed symbols plotted on vertical and horizontal axes, respectively, in geographic coordinates. Thermal demagnetization levels (in degrees Celcius) in all diagrams except c, which is alternating field demagnetization (mT). (a and b) Samples of gray mudstones from upper Cow Branch Member with a recent overprint and reverse (a) and normal (b) polarity Cm characteristic components carried by magnetite; (c) is a companion specimen to (a) and shows that alternating field demagnetization is not effective to isolate characteristic magnetization; (d) is a sulfide-bearing sample with a barely resolvable $\mathrm{Cm}$ component with reverse polarity. (e and f) Samples from red rock types of Leakesville Formation with recent $(\mathrm{A})$ and ancient (Bh) overprints, as well as normal (e) and reverse (f) polarity Ch characteristic components carried by hematite.

in close association with deposition, either as depositional or early diagenetic remanences. We explore some of the consequences of this conjecture by analysis of the polarity stratigraphy and paleomagnetic poles.

\section{MAGNETOSTRATIGRAPHY}

A virtual geomagnetic pole (VGP) was calculated for each site-mean characteristic component direction after correction for bedding tilt and was used to determine an overall mean paleomagnetic reference pole (Table 2). The latitude of the site VGP relative to the north axis of the mean reference pole provides a diagnostic index of polarity for the delineation of magnetozones, approaching $+90^{\circ}$ for normal polarity and $-90^{\circ}$ for reverse polarity. Identification of local magnetozones follows the nomenclature of Kent et al. (1995), in this case using the prefix D for the Dan RiverDanville basin, an integer in ascending order from the base of the sampled section to successive normal and reverse polarity magnetozone couplets, and a suffix for the polarity ( $\mathrm{n}$ for normal, $\mathrm{r}$ for reverse) of the constituent magnetozones.

The magnetostratigraphy of the Eden section is based on characteristic magnetizations from 25 sites which delineate 5 magnetozones (D1n to D3n), whereas data from 88 sites in the longer Cascade section delineate 9 main magnetozones
(D1r to D5r) (Fig. 5). The Eden section should overlap with the basal part of the Cascade section according to regional stratigraphic relations (Fig. 1c), and this is supported by the good match in polarity magnetozones between the two sections. The lower $1700 \mathrm{~m}$ of the Cascade section is predominantly of reverse polarity, but is punctuated by three normal magnetozones that are each $\approx 100 \mathrm{~m}$ thick, two (D2n, D3n) in the unnamed member in lower part of the section, which are also found in the Eden section, and another (D4n) that occurs at about the $1250 \mathrm{~m}$ level in the upper Cow Branch Member. All reliable sites in the New, Main, and Old quarries are from magnetite-bearing rocks and 
TABLE 1. PALEOMAGNETIC COMPONENT DIRECTIONS FROM THE DAN RIVER-DANVILLE BASIN

\begin{tabular}{|c|c|c|c|c|c|c|c|c|c|}
\hline & \multirow[b]{2}{*}{$\mathrm{N}$} & \multicolumn{4}{|c|}{ Geographic } & \multicolumn{4}{|c|}{ Tilt corrected } \\
\hline & & $\begin{array}{l}\text { D } \\
\left({ }^{\circ}\right)\end{array}$ & $\begin{array}{c}1 \\
\left({ }^{\circ}\right)\end{array}$ & k & $\begin{array}{c}\alpha_{95} \\
\left(^{\circ}\right)\end{array}$ & $\begin{array}{c}\text { D } \\
\left({ }^{\circ}\right)\end{array}$ & $\begin{array}{c}1 \\
\left({ }^{\circ}\right)\end{array}$ & $\mathrm{k}$ & $\begin{array}{c}\alpha_{95} \\
\left({ }^{\circ}\right)\end{array}$ \\
\hline$A$ & 142 & 351.8 & 54.3 & 44.8 & 1.8 & 337.1 & 27.1 & 27.5 & 2.3 \\
\hline $\mathrm{Bh}$ & 57 & 8.5 & 40.4 & 44.5 & 2.9 & 357.2 & 18.2 & 36.1 & 3.2 \\
\hline \multicolumn{10}{|l|}{$\underline{\mathrm{Cm}}$} \\
\hline Normal & 14 & 14.4 & 23.5 & 42.2 & 6.2 & 3.6 & 7.8 & 47.6 & 5.8 \\
\hline Reverse & 46 & 188.1 & -22.0 & 31.2 & 3.8 & 181.7 & -0.3 & 30.4 & 3.9 \\
\hline $\mathrm{N}+\mathrm{R}$ & 60 & 9.6 & 22.4 & 32.6 & 3.3 & 2.1 & 2.1 & 31.9 & 3.3 \\
\hline \multicolumn{10}{|l|}{ Ch } \\
\hline Normal & 23 & 4.5 & 26.9 & 21.4 & 6.7 & 358.6 & 5.2 & 24.7 & 6.2 \\
\hline Reverse & 30 & 184.3 & -28.8 & 18.7 & 6.2 & 177.8 & -5.5 & 27.4 & 5.1 \\
\hline $\mathrm{N}+\mathrm{R}$ & 53 & 4.4 & 28.0 & 20.1 & 4.5 & 358.2 & 5.4 & 26.7 & 3.9 \\
\hline \multicolumn{10}{|l|}{$\underline{\mathrm{Cm}}+\mathrm{Ch}$} \\
\hline$\overline{\text { Normal }}$ & 37 & 8.3 & 25.7 & 24.8 & 4.8 & 0.5 & 6.2 & 29.9 & 4.4 \\
\hline Reverse & 76 & 186.4 & -24.3 & 22.8 & 3.5 & 180.1 & -2.4 & 28.3 & 3.1 \\
\hline $\mathrm{N}+\mathrm{R}$ & 113 & 7.2 & 25.0 & 24.3 & 2.8 & 0.3 & 3.6 & 28.7 & 2.5 \\
\hline
\end{tabular}

indicate reverse polarity. The upper part of the section is dominated by a thick normal polarity magnetozone (D5n) from $\approx 1700 \mathrm{~m}$ to $2400 \mathrm{~m}$ that is overlain by two reverse polarity sites corresponding to magnetozone D5r. The upper limit of magnetozone D5r is not well defined, although data from an isolated hand sample suggest a return to normal polarity (D6n) by $\approx 2750 \mathrm{~m}$.

The Cascade and Eden sections were merged to produce a composite Dan River-Danville magnetostratigraphy that includes 11 magnetozones over $\approx 3000 \mathrm{~m}$ of stratigraphic section (Fig. 6). All magnetozones except for D6n are each defined by two or more sites. Of the total number of sampled sites, $\approx 70 \%$ provided useful paleomagnetic data, most of the attrition occurring in the gray mudstones of the upper Cow Branch Member in the Cascade section and resulting in several data gaps of $\approx 100 \mathrm{~m}$ thickness. In addition, there is a large sampling gap of $\approx 250 \mathrm{~m}$ in magnetozone D5r, due to poor exposure and the presence of buff coarse sandstones and conglomerates that we did not sample.

Correlation of the Dan River-Danville composite section to the Newark reference sequence (Kent et al., 1995) can be made on the basis of biostratigraphic constraints and then optimized with magnetostratigraphy (Fig. 6). The upper Cow Branch Member is late Carnian in age, according to biostratigraphy (Olsen and Gore, 1989), and should thus broadly correspond to the Lockatong Formation of the Newark basin. This association allows an excellent match of the magnetozones in which D1n to D6n of the Dan River-Danville basin corresponds to E9n to E14n of the Newark basin. Within this target interval, only the equivalent of the very thin sub- magnetozone E13n.1r is was apparently missed in the Dan River-Danville section, and may fall within a data gap in magnetozone D5n.

The correlation to the cyclostratigraphically calibrated Newark time scale indicates that the Dan River-Danville sampled section represents $\approx 7.5$ m.y. of the Carnian and earliest Norian, from ca. 224.5 Ma to perhaps $217 \mathrm{Ma}$. The 3000-mthick Dan River-Danville section evidently accumulated at a net rate of $\approx 400 \mathrm{~m} / \mathrm{m}$.y., which is 2.5 times higher than the average of $\approx 160 \mathrm{~m} / \mathrm{m}$.y. for the correlative part of the Newark composite section (Fig. 7). Nevertheless, both sections show a general increase in sediment accumulation rates going upsection over this interval, from $\approx 240 \mathrm{~m} / \mathrm{m}$.y. to $500 \mathrm{~m} / \mathrm{m}$.y. in the Dan RiverDanville section, and from $\approx 140 \mathrm{~m} / \mathrm{m}$.y. to $200 \mathrm{~m} / \mathrm{m}$.y. in the Newark section.

\section{LITHOSTRATIGRAPHY}

An obvious counterpart of the gray mudstones of the upper Cow Branch Member of the Leakesville Formation is the Lockatong Formation of the Newark basin; both units reflect a similar response to generally humid conditions near the paleoequator. However, the magnetostratigraphic correlations reveal that persistent gray mudstones appear a little later in the Dan River-Danville section, just above magnetozone D3n (=E11n) compared to magnetozone E10n $(=\mathrm{D} 2 \mathrm{n})$ in the Newark section, where they define the base of the Lockatong Formation. In addition, gray mudstones of the upper Cow Branch Member do not pass into persistent red siltstones until the uppermost part of magnetozone D5n (=E13n), compared to the lower part of E13n $(=\mathrm{D} 5 \mathrm{n})$ in the Newark Basin Coring Project cores from the Newark basin, where the appearance of a dominant red lithology defines the local base of the Passaic Formation. These apparent age offsets of $\approx 1$ m.y. in some of the lithofacies between the Newark and the Dan RiverDanville sequences may reflect local tectonic effects on deposition. In this regard, we note also that the lacustrine gray mudstones of the lower Cow Branch Member, which we did not sample but by superposition must be older than magnetochron E9n (=D1n), have no immediately obvious counterparts in the age-correlative Stockton Formation, which is predominantly of fluvial and shallow water lacustrine facies.

Cyclic intervals of the upper Cow Branch Member are well exposed in the New, Old, and especially the Main quarries. On the basis of the magnetostratigraphic correlations to the Newark basin, the New quarry most likely corresponds to the gray mudstones of the Nursery Member, the Main quarry to the Byram and basal Skunk Hollow Members, and the Old quarry to the lower part of the Prahls Island Member (Fig. 6). The Main quarry section is $\approx 175 \mathrm{~m}$ thick (Old and New quarry sections are $\approx 65$ and $110 \mathrm{~m}$ thick, respectively), and at an estimated average sediment accumulation rate of $450 \mathrm{~m} / \mathrm{m}$.y. (Fig. 7), should therefore encompass most of a 413 k.y. Milankovitch eccentricity climate cycle. Measurements of relative lake level based on depth ranking of sediment facies in the quarries show evidence for Milankovitch climate cycles with periods of $\approx 100 \mathrm{k} . \mathrm{y}$. and $23 \mathrm{k} . \mathrm{y}$., as well as $\approx 12 \mathrm{k} . \mathrm{y}$., which may represent the predicted frequency doubling of the precession climate cycle near the paleoequator.

\section{PALEOMAGNETIC POLES}

The successful magnetostratigraphic correlation of the Dan River-Danville section to the Newark reference sequence makes possible a precise comparison of the corresponding coeval paleopoles to test the tectonic coherence of the two basins. The paleomagnetic north pole calculated from the 113 site-mean VGPs from the Dan River-Danville basin is located at $55.4^{\circ} \mathrm{N}$, $100.1^{\circ} \mathrm{E}, \mathrm{A}_{95}=1.9^{\circ}$ (Fig. 8; Table 2). This late Carnian Dan River-Danville paleopole is within $2.1^{\circ}$ and not significantly different from the lower Newark outcrop pole of mainly late Carnian age $\left(53.5^{\circ} \mathrm{N}, 101.6^{\circ} \mathrm{E}\right.$; Witte and Kent, 1989). The Dan River-Danville paleopole is also within $2.0^{\circ}$ and is not significantly different from the pole for the Nursery drill core $\left(54.1^{\circ} \mathrm{N}, 102.8^{\circ} \mathrm{E}\right.$; Kent et al., 1995), the Newark Basin Coring Project stratigraphic cored interval that corresponds most closely to the Dan River-Danville sampled section. The close correspondence of coeval Dan River-Danville and Newark basin poles makes it 


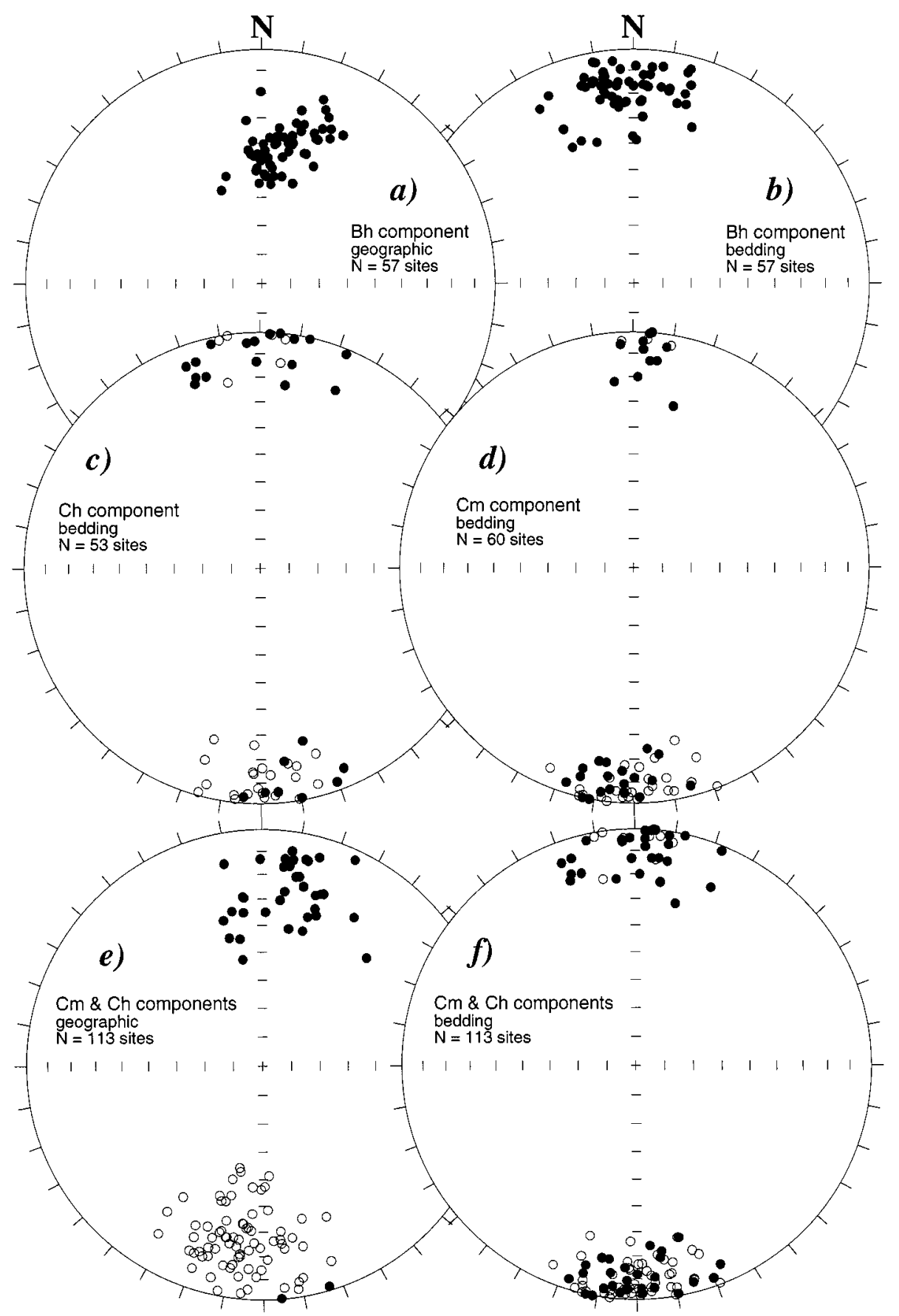

Figure 4. Equal-area projections of site means of $(a, b)$ Bh component before and after tilt correction, (c) Ch component and (d) $\mathrm{Cm}$ component after tilt correction, and (e, f) the $\mathrm{Cm}$ and Ch components together before (e) and after (f) tilt correction. Closed and open symbols are on lower and upper hemispheres, respectively.

highly improbable that the main parts of these widely separated basins have rotated with respect to each other.

The Bh component isolated in the Dan RiverDanville basin section is similar to the B component found as an ubiquitous overprint in the Newark basin (Witte and Kent, 1991). Both the Dan major hydrothermal event at ca. $175 \mathrm{Ma}$ (Witte and Kent, 1991). Although the limited structural variation in the sampled section precludes a statistically diagnostic fold test, it is reasonable to suppose that the Bh component also represents a secondary magnetization acquired late in the structural evolution of the Dan River-Danville basin. The Bh paleopole with no correction for bedding tilts is located at $74.7^{\circ} \mathrm{N}, 69.4^{\circ} \mathrm{E}, \mathrm{A}_{95}$ $=2.8^{\circ}$ (Table 2 ). This falls near the $\mathrm{B}$ paleopole at $74^{\circ} \mathrm{N}, 96^{\circ} \mathrm{E}, \mathrm{A}_{95}=2.6^{\circ}$ from the main part of the Newark basin, consistent with a mid-Jurassic age and a high-latitude model of Jurassic apparent polar wander (APW) for North America (Witte and Kent, 1989, 1991; Van Fossen and Kent, 1990; Kodama and Mowery, 1994; see also Hagstrum, 1993, and Courtillot et al., 1994, for reviews of Jurassic APW).

\section{DISCUSSION}

Assessments of the rate of APW for North America in the Late Triassic and the amount of rotation of the Colorado Plateau, where many reference paleopoles for North America have been derived, are strongly interrelated. On the basis of the paleomagnetic record from the Newark basin, with supporting evidence from other cratonic localities, Kent and Witte (1993) concluded that APW for North America was slow in the Late Triassic and that the relative discordance of Late Triassic poles from the southwestern United States must therefore be related to a large $\left(\approx 10^{\circ}-15^{\circ}\right)$ net clockwise rotation of the Colorado Plateau. In the most recent analysis expressing the opposite view, Molina-Garza et al. (1995) maintained that Colorado Plateau rotation was small $\left(\approx 5^{\circ}\right.$ clockwise), and attributed the resulting distribution of Late Triassic poles from the Colorado Plateau toward the so-called J-1 cusp as evidence for fast APW ( $\approx 0.8^{\circ} / \mathrm{m}$.y. $)$. These conflicting models of APW have important consequences for the paleolatitudinal framework for rocks indicative of paleoclimates in the Newark rift basins.

Fast APW in the Late Triassic is incompatible with the most complete paleomagnetic record of Upper Triassic rocks available from a single tectonic entity, the Newark basin, which includes a fold test and a coherent magnetostratigraphy, and receives further support for reliability from the Dan River-Danville basin results. The Newark basin lower and middle outcrop strata poles, plus results from the Manicouagan impact structure in Quebec, Upper Shale in eastern New Mexico, Dockum Group in northwest Texas, and now also from the Dan River-Danville basin, provide a good approximation of the Late Triassic pole for cratonic North America at $56.3^{\circ} \mathrm{N}$, $94.3^{\circ} \mathrm{E}\left(\mathrm{N}=6, \mathrm{~A}_{95}=2.9^{\circ}\right)$. The close grouping 


\begin{tabular}{|c|c|c|c|c|}
\hline & $\overline{\mathrm{N}}$ & $\begin{array}{l}\text { Lat } \\
\left({ }^{\circ} \mathrm{N}\right)\end{array}$ & $\begin{array}{l}\text { Long } \\
\left({ }^{\circ} \mathrm{E}\right)\end{array}$ & $\begin{array}{c}A_{95} \\
\left({ }^{\circ}\right)\end{array}$ \\
\hline A (geographic) & 142 & 83.1 & 178.5 & 2.2 \\
\hline Bh (geographic) & 57 & 74.7 & 69.4 & 2.8 \\
\hline $\mathrm{Cm}+\mathrm{Ch}$ (bedding) & 113 & 55.4 & 100.1 & 1.9 \\
\hline \multicolumn{5}{|c|}{$\begin{array}{l}\text { Note: } \mathrm{N} \text { is number of site virtual geomagnetic poles for } \\
\text { calculating latitude (Lat) longitude (Long) and radius of } 95 \% \\
\text { circle of confidence }\left(\mathrm{A}_{95}\right) \text { of paleomagnetic poles for each } \\
\text { component. }\end{array}$} \\
\hline
\end{tabular}

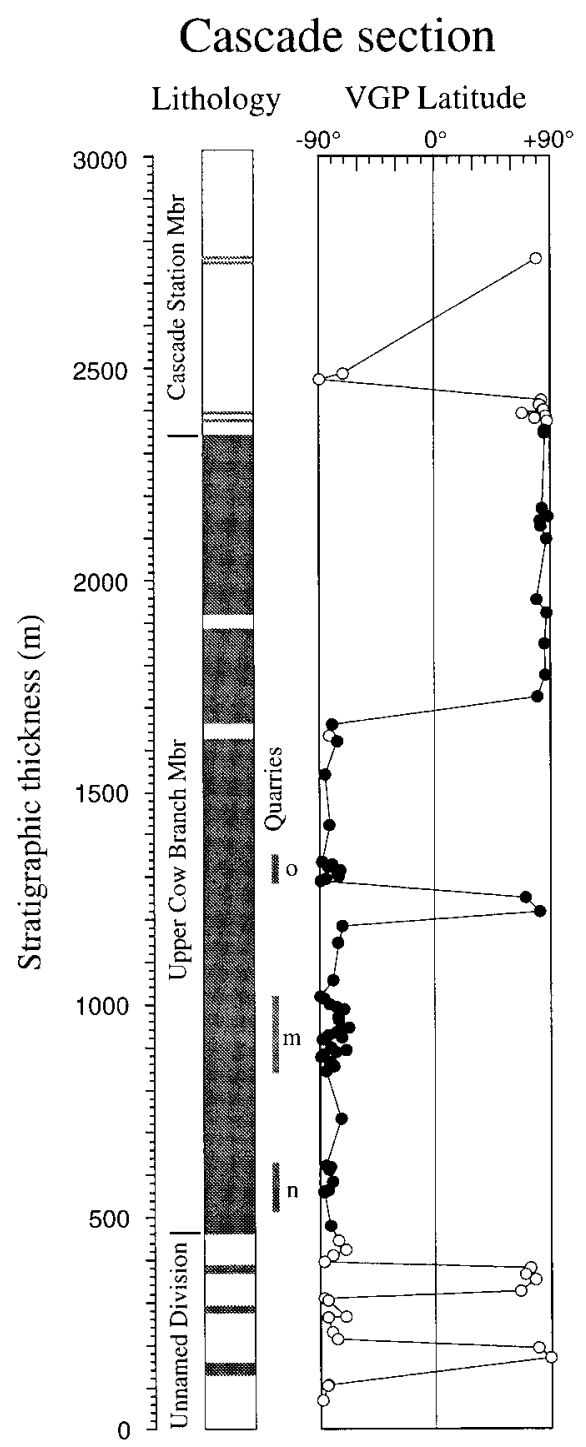

\section{Composite Magnetic Polarity}

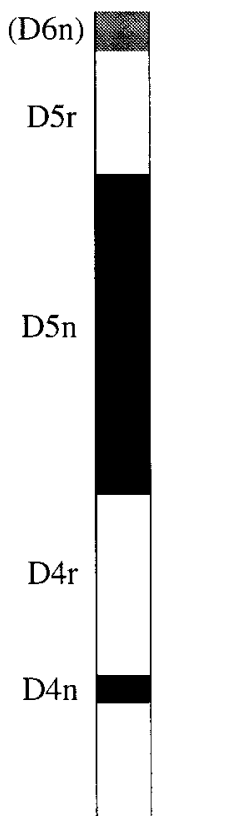

of these paleopoles suggests that the Late Triassic was an interval of slow APW $\left(\approx 0.3^{\circ} / \mathrm{m}\right.$.y. or less), the progress of which can just be delineated by the high-resolution Newark Basin Coring Project drill core poles (Kent et al., 1995) (Fig. 8). Paleomagnetic results from the Redonda Formation of eastern New Mexico reported by Reeve and Helsley (1972) are anomalous in this regard. Lucas et al. (1993) considered the Redonda as late Norian or Rhaetian in age and correlative to the upper part of the Passaic Formation, but the Redonda pole cited by MolinaGarza et al. (1995) does not agree with the Newark basin poles (Fig. 8). Relative rotations of the Newark basin(s) or of eastern New Mexico do not provide a viable explanation for the disagreement given the concordance of the Newark basin, Dan River-Danville basin, and Upper Shale paleopoles. However, Reeve and Helsley (1972) recognized that the directions obtained after demagnetization to only $550{ }^{\circ} \mathrm{C}$ for the hematite-bearing rocks in this initial study of the Redonda are likely to be contaminated by secondary components, perhaps similar to those corresponding to the Tecovas B secondary pole reported from northwest Texas (Molina-Garza et al., 1995). The existing results from the Redonda should therefore be considered of uncertain significance, and we note that the various pole permutations in this early study were ultimately excluded in the analysis of APW by Bazard and Butler (1991). Paleomagnetic results from sedimentary rocks interbedded with volcanic rocks

\section{Eden section}

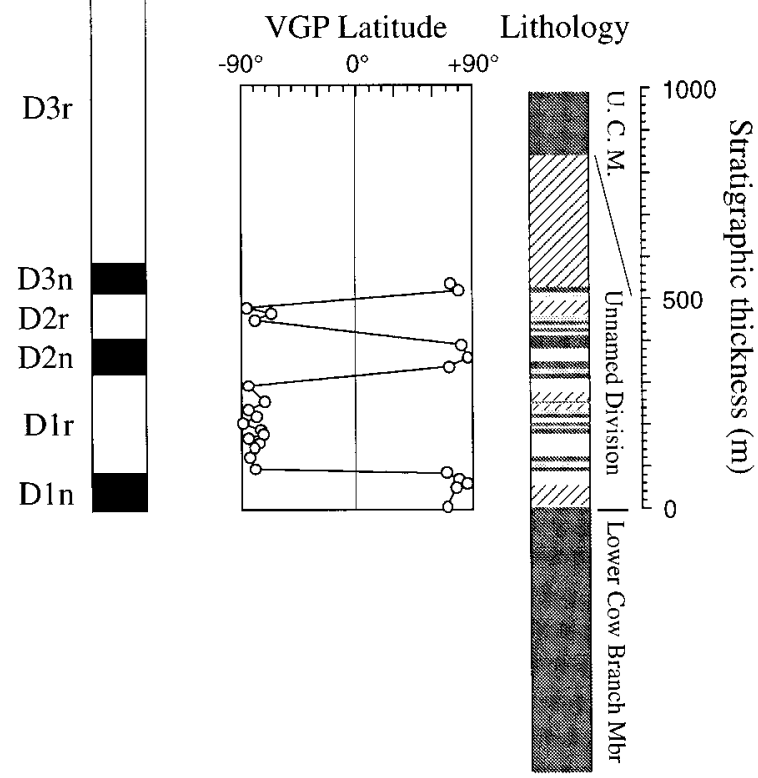

Figure 5. Lithology (diagonal lines for covered intervals; see Fig. 1 for key to other patterns), virtual geomagnetic pole relative latitudes (open and closed circles for hematite and magnetite magnetizations, respectively), and composite polarity interpretation (filled is normal, open is reverse) for Cascade section (left; position of old, main, and new quarries indicated by $\mathbf{o}, \mathbf{m}$, and $\mathbf{n}$, respectively) and the Eden section (right) from the Dan River-Danville basin. 


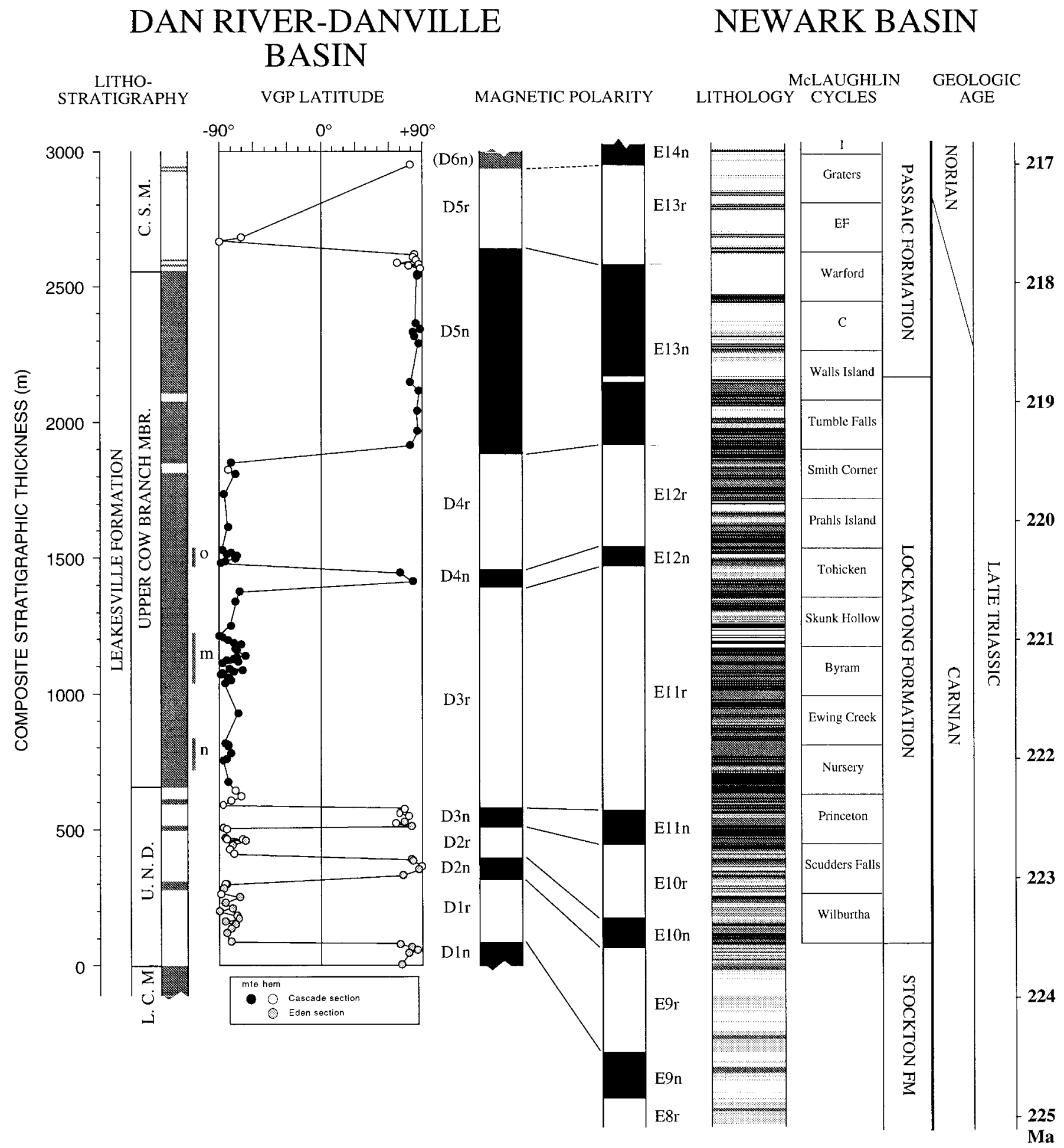

Figure 6. Correlation of composite magnetostratigraphy for Dan River-Danville basin to the reference geomagnetic polarity sequence from the Newark basin (Kent et al., 1995). See Figures 1 and 5 for description of symbols.

in the Newark extrusive zone indicate that the Late Triassic interval of slow APW extended into the first 1 m.y. or so of the earliest Jurassic (Witte and Kent, 1990).
In contrast, Molina-Garza et al. (1995) argued that Late Triassic APW for North America was fast to arrive at the $\mathrm{J}-1$ cusp at $60.9^{\circ} \mathrm{N}, 65.6^{\circ} \mathrm{E}$, which is $30^{\circ}$ more westerly in longitude or $\approx 15^{\circ}$ of total arc distance from the Newark-related poles (Fig. 8). However, paleopoles from North America cited by these authors as falling near to the J-1 cusp are either Jurassic in age or, if Trias- 


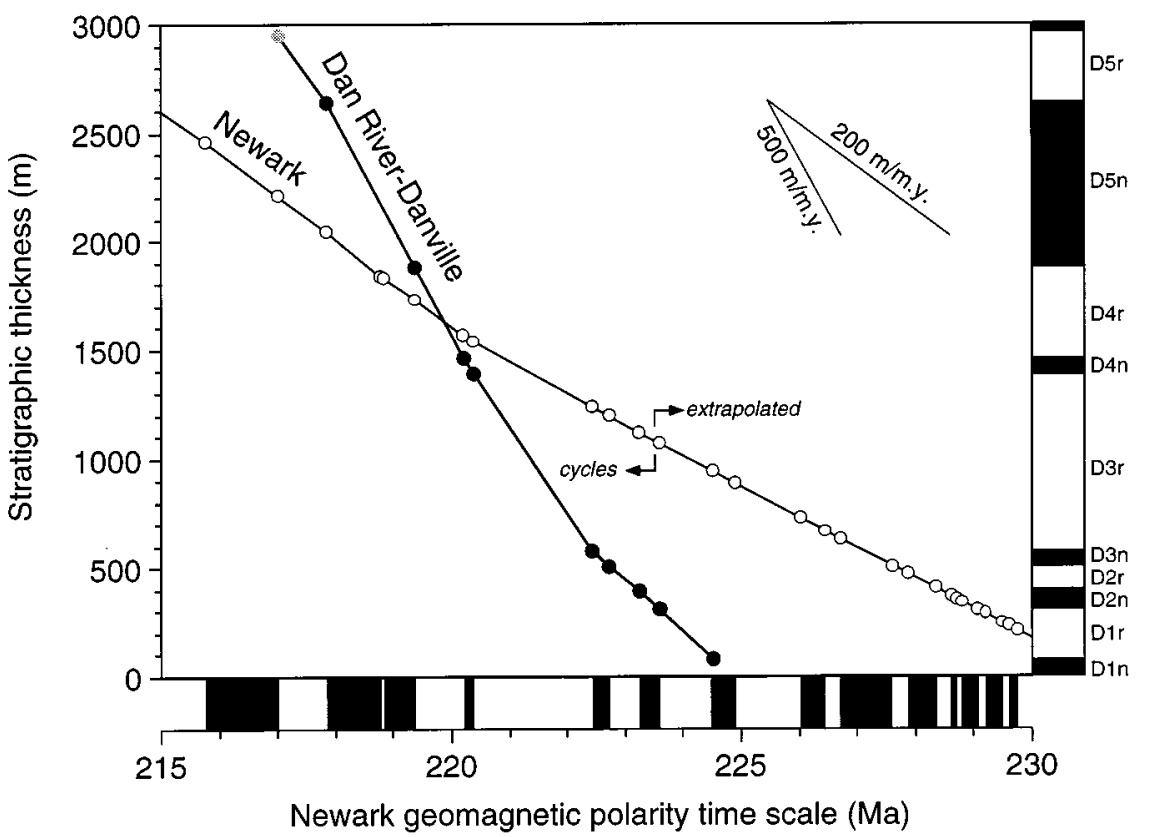

Figure 7. Sediment thickness versus age of polarity intervals according to cyclostratigraphically calibrated Newark polarity time scale (Kent et al., 1995) for Dan River-Danville basin section and for the correlative part of Newark basin section. Slope of lines is average sediment accumulation rate. Note that there is no direct cyclostratigraphic age control for older than ca. 223.5 Ma in the Newark section (Stockton Formation; E9r and older), where the polarity time scale was based on extrapolation of sediment accumulation rate from the overlying Lockatong Formation. sic, come from the Colorado Plateau. The ages of the cited magnetizations from the Piedmont dikes (Smith, 1987), Newark-Culpeper igneous dikes and sills and associated baked sedimentary rocks (Kodama et al., 1994b), and the Tecovas B secondary pole (Molina-Garza et al., 1995) are not precisely known, but are most likely Early Jurassic. There are other complications in the interpretation of these results. For example, the mean directions for baked sedimentary rocks from the Newark and Culpeper basins do not agree (Kodama et al., 1994b), which might suggest that paleosecular variation was not averaged adequately for a reliable paleopole position. An igneous contact test is also negative with respect to the baked sedimentary rocks in the Newark basin, which was interpreted by Kodama et al. (1994b) as further indication that Newark igneous intrusions are often affected by remagnetizations (Witte and Kent, 1991; Kodama and Mowery, 1994). These considerations would not explain the disagreement between the Tecovas B secondary pole (Molina-Garza et al., 1995) and the earliest Jurassic sedimentary pole from the Newark basin (Witte and Kent, 1990), but it cannot be excluded that the Tecovas B secondary pole with normal and reverse polarities is younger than the Newark early Hettangian pole with only normal polarity. Fast APW is therefore possible in the Jurassic

Figure 8. Paleopole from the Dan RiverDanville basin (DRD) compared to diagnostic Late Triassic paleopoles from the Newark basin and elsewhere in North America shown by $95 \%$ confidence circles or ovals (shaded for cratonic sites, unshaded for Colorado Plateau sites). The following poles are tabulated and referenced in Kent and Witte (1993) and/or Molina-Garza et al. (1995): NWl-lower Newark basin outcrop strata, NWm-middle Newark basin outcrop strata, US-Upper Shale Member of Chinle Formation from eastern New Mexico, MI-Manicouagan impact structure in Quebec, DO-Dockum Group from west Texas, CR1 and CR2-Church Rock Member of Chinle Formation from Utah, OR-Owl Rock Member of Chinle Formation from Arizona, and J-1-Late Triassic-Early Jurassic mean reference pole (shown for clarity without confidence circle of $5.1^{\circ}$ )

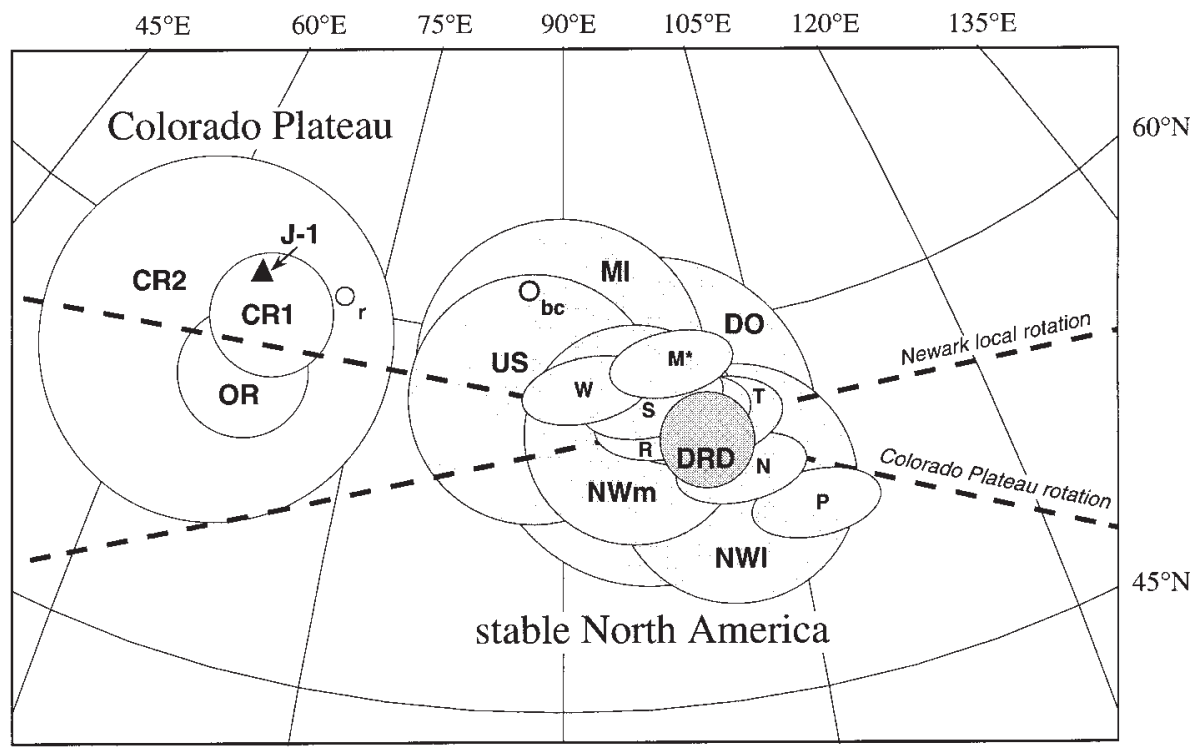
proposed by Molina-Garza et al. (1995).

Newark Basin Coring Project drill core poles from Kent et al. (1995), from older to younger, are P-Princeton, N-Nursery, T-Titusville, R-Rutgers, $\mathrm{S}$-Somerset, $\mathrm{W}$-Weston, $\mathrm{M}^{*}$-Martinsville, recalculated to exclude earliest Jurassic strata $\left(\mathbf{5 8 . 5} \mathbf{5}^{\circ} \mathrm{N}, \mathbf{9 8 . 2}^{\circ} \mathrm{E} ; \mathrm{dp}, \mathrm{dm}=1.5^{\circ}, \mathbf{2 . 9}^{\circ} ; \boldsymbol{n}=\mathbf{3 0 2}^{\circ} \mathrm{sam}\right.$ ples), but which hardly differs from the original $\left(58.6^{\circ} \mathrm{N}, 98.4^{\circ} \mathrm{E} ; \mathrm{dp}, \mathrm{dm}=1.4^{\circ}, 2.7^{\circ} ; n=340\right.$ samples). Also shown (without confidence circles) are Redonda (r) and Bluewater Creek (bc) poles used by Molina-Garza et al. (1995), but which are regarded here as unreliable for apparent polar wander analysis (see text). Dashed lines indicate expected trajectories of poles if affected by rotation of the Colorado Plateau or by a local vertical axis rotation in the Newark basin. 
after the early Hettangian to account for the Tecovas B and some other Early Jurassic poles such as from the Sinemurian Moenave Formation (Ekstrand and Butler, 1989), but there is no compelling evidence for fast APW in the Late Triassic.

Slow APW for North America in the Late Triassic implies that net rotation of the Colorado Plateau was most likely greater than $5^{\circ}$ clockwise to explain the large discordance in Late Triassic poles that are demonstrably from the plateau (Fig. 8). Unfortunately, a paleopole from the Carnian Bluewater Creek Formation was used as the sole representative of the Late Triassic pole for the Colorado Plateau by Molina-Garza et al. (1995); this pole was obtained from exposures on the east side of the Rio Grande rift in central New Mexico, a structurally complicated area adjacent to the plateau that may have rotated with the Colorado Plateau or via an independent deformation mechanism (Molina-Garza et al., 1991). The unknown tectonic coherence of the east side of the Rio Grande Rift casts doubt on the significance of the Carnian Bluewater Creek pole for APW analysis. There is no ambiguity, however, about the plateau coherence of the Church Rock and Owl Rock units from Arizona and Utah (Fig. 8), subdivisions of the Chinle that are regarded as being the same age as the Passaic Formation in the Newark basin (e.g., see correlation diagram in Bazard and Butler, 1991, and references cited therein). The divergence of these Chinle results with respect to the coeval Newark and other Late Triassic poles from cratonic North America thus cannot be attributed to fast APW, but more plausibly constitutes evidence for a large $\left(\approx 10^{\circ}-15^{\circ}\right)$ net clockwise rotation of the Colorado Plateau since the Triassic (Kent and Witte, 1993). Similar conclusions for large plateau rotation were reached by Steiner (1986) to explain a systematic discordance in Early to Middle Triassic poles for North America, and by Courtillot et al. (1994), based on an analysis of Jurassic paleopoles from North America with respect to synthetic transferred APW paths from other Atlantic-bordering continents.

Returning to the paleogeographic implications, we note that rotation of the Colorado Plateau has comparatively little effect on paleolatitudinal estimates for the plateau, but if the amount of Plateau rotation is misdiagnosed, has more serious consequences for paleolatitudes predicted for more distant localities such as in eastern North America (Fig. 9). For example, for a locality on the Colorado Plateau (e.g., $30^{\circ} \mathrm{N}$, $\left.109^{\circ} \mathrm{W}\right)$, a latest Triassic paleolatitude of $6^{\circ} \mathrm{N}$ is predicted from our preferred mean Late Triassic pole for cratonic North America $\left(56.3^{\circ} \mathrm{N}\right.$, $\left.95.3^{\circ} \mathrm{E}\right)$, not very different from $8^{\circ} \mathrm{N}$ from the proposed $\mathrm{J}-1$ pole $\left(60.9^{\circ} \mathrm{N}, 65.6^{\circ} \mathrm{E}\right.$; MolinaGarza et al., 1995). However, using these same

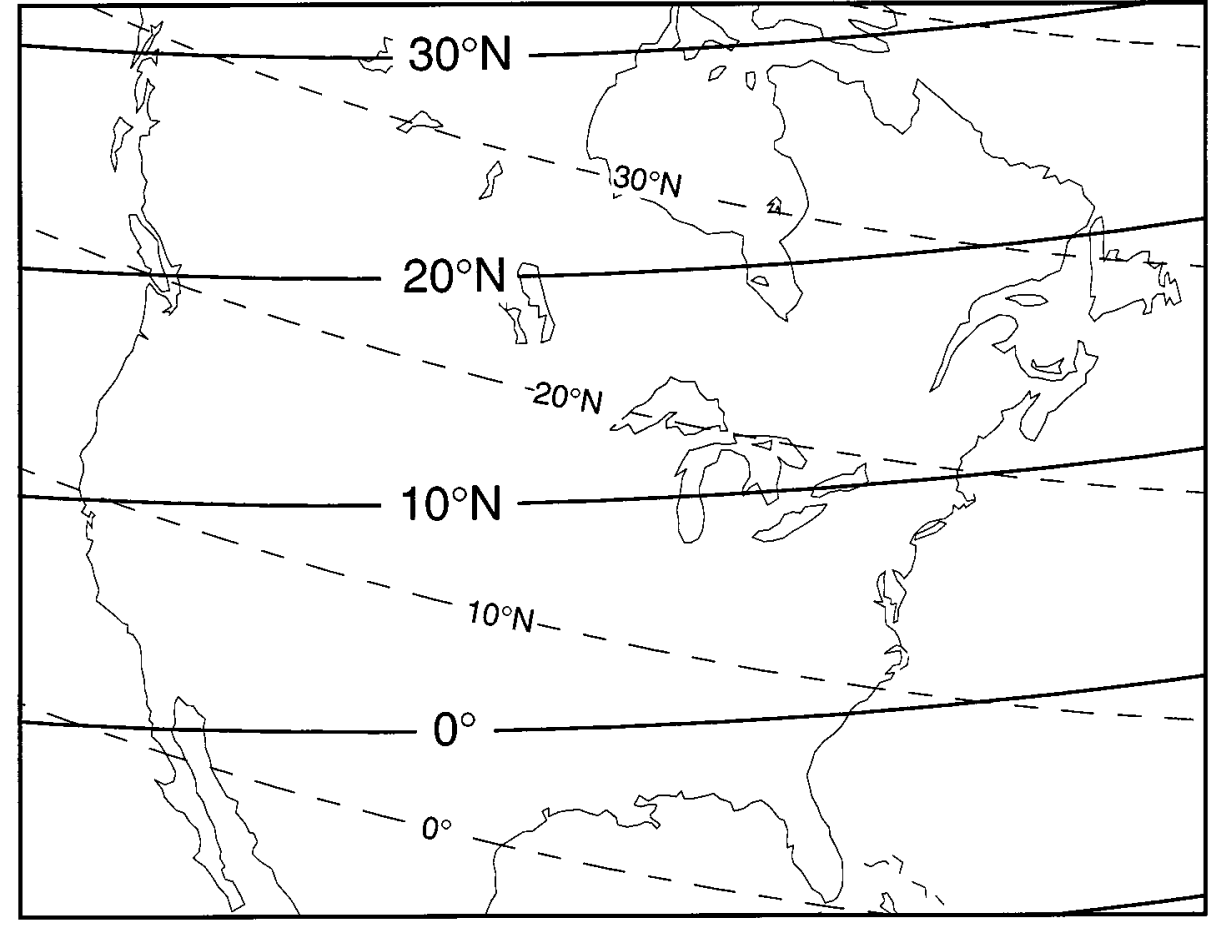

Figure 9. Paleolatitudes for North America for the latest Triassic based on our preferred mean cratonic pole $\left(56.3^{\circ} \mathrm{N}, 94.3^{\circ} \mathrm{E}\right)$ shown in heavy lines, or the $\mathrm{J}-1$ pole $\left(60.9^{\circ} \mathrm{N}, 65.6^{\circ} \mathrm{E}\right.$; Molina-Garza et al., 1995) shown in dashed lines. Note the similarity in paleolatitudes for western North America with either reference pole, but the significantly higher paleolatitudes predicted for eastern North America with the J-1 model.

pole positions to predict latest Triassic paleolatitudes for a locality in the Newark basin (e.g., $41^{\circ} \mathrm{N}, 74^{\circ} \mathrm{W}$ ) gives $8^{\circ} \mathrm{N}$ or virtually the same as observed for the preferred cratonic reference, but $17^{\circ} \mathrm{N}$ for the $\mathrm{J}-1$ pole (i.e., plateau poles corrected for only $5^{\circ}$ clockwise rotation). What this means in pole space is that rotation of the Colorado Plateau about a nearby net Euler pole (Hamilton, 1981, 1988) can transform a Late Triassic Newark reference pole into a J-1 cusp direction (Fig. 8). However, a local vertical axis rotation in the Newark basins cannot similarly transform a Late Triassic Newark reference pole into a $\mathrm{J}-1$ cusp direction (or the converse) because the observed inclinations or corresponding paleolatitudes do not change, as would be needed in this case for the poles to come into agreement.

A paleolatitude of $\approx 2^{\circ}$ that we obtained for the gray mudstone-dominated section in the Dan River-Danville basin that is locally coal bearing agrees with paleoclimatological interpretations of such facies as indicators of the high humidity that is expected very near the paleoequator (e.g., Blackett, 1961; Briden and Irving, 1964; Parrish et al., 1982). Our preferred mean Late Triassic paleopole for cratonic North America $\left(56.3^{\circ} \mathrm{N}\right.$, $94.4^{\circ} \mathrm{E}, \mathrm{A}_{95}=2.9^{\circ}$ ), which includes the Dan River-Danville pole, is hardly different from the late Carnian-early Norian mean paleopole $\left(53.0^{\circ} \mathrm{N}, 94.4^{\circ} \mathrm{E}, \mathrm{A}_{95}=3.6^{\circ}\right)$ of Molina-Garza et al. (1995) but which, unlike their latest Triassic and Early Jurassic J-1 pole, does not happen to include any poles demonstrably from the Colorado Plateau (see previous comments on Bluewater Creek Formation). Thus, whereas the APW model of Molina-Garza et al. (1995) would suggest that the east coast of North America moved rapidly and appreciably northward in the latest Triassic-for example, to $17^{\circ} \mathrm{N}$ for the Newark basin. We would ascribe most of this apparent paleolatitudinal change as an artifact of the inclusion of rotated plateau poles and younger (Jurassic) poles in the J-1 mean.

\section{CONCLUSIONS}

Magnetostratigraphy has provided a precise correlation of Upper Triassic continental sedimentary rocks from the Dan River-Danville and Newark basins. The close correspondence of the coeval paleomagnetic poles indicates that there has been no relative rotation between the main parts of these basins, consistent with the overall 
cratonic coherence of the rift basins on the basis of structural evidence (Lindholm, 1978; Ratcliffe et al., 1986; Swanson, 1986). Rotated paleomagnetic poles reported from some Newark basins (e.g., Kodama et al., 1994a) are likely to reflect localized structural complications associated with sampling in proximity to major faults.

The J-1 model for North America APW in the Late Triassic (Molina-Garza et al., 1995) makes paleolatitudinal predictions that are not substantiated in the Newark record, for example, predicting a paleolatitude of $17^{\circ} \mathrm{N}$ for the latest Triassic in the Newark basin compared to less than $10^{\circ} \mathrm{N}$ observed. The discrepancy is attributed to a $10^{\circ}-15^{\circ}$ clockwise rotation of the Colorado Plateau which previous work has shown would also help reconcile Early Triassic paleopoles from the plateau with cratonic counterparts. Rotation of the Colorado Plateau, first put forward by Hamilton (1981) on geological grounds, is widely accepted, and although a seemingly large $\left(10^{\circ}-15^{\circ}\right)$ rotation may pose a challenge to some estimates of how it was accommodated by Laramide shortening and subsequent Cenozoic extension (e.g., Chase et al., 1992), it is nonetheless the most parsimonious explanation for the Late Triassic as well as the Early Triassic (Steiner, 1986) paleomagnetic record for North America. If correct, our model for North American APW still predicts (Kent and Witte, 1993) that a complete stratigraphic sequence of Late Triassic poles from the Colorado Plateau should show a similar slow evolution as observed for the sequence of Newark basin poles, but be systematically offset by $\approx 30^{\circ}$ of longitude because of a $10^{\circ}-15^{\circ}$ net clockwise rotation of the Colorado Plateau in the late Mesozoic and Cenozoic.

Coal deposits, indicators of high humidity, are known only from the southern Newark Supergroup basins, including the Dan River-Danville basin (Robbins et al., 1988), whereas evidence for aridity comes principally from the northern Newark Supergroup basins, most definitively from the Fundy basin of Nova Scotia, where an eolian dune field has been described in the uppermost Wolfville Formation (Hubert and Mertz, 1980). Although local tectonic and orographic controls on the sediment facies and climates undoubtedly played a role, the general trends of increasing aridity from south to north as well as less humid conditions upsection that are well recognized in the Newark Supergroup sedimentary sequences (e.g., Smoot, 1991) are consistent with climatic variations across paleolatitudes as North America drifted slowly northward. Resolving the problem of paleomagnetically determined paleolatitudes for the Late Triassic of eastern North America is important because they provide an independent and precise paleogeo- graphic framework for interpreting the evolution of paleoclimatic gradients and calibrating climate models for Pangea in general (Crowley, 1994). In this regard, although paleopoles from the Fundy basin region (Middle to Upper Triassic Agamenticus and Abbott plutons, Wu and Van der Voo, 1988; lower Fundy Group sedimentary rocks, Symons et al., 1988) may be older than the Late Triassic poles considered here, the mean pole position of $47^{\circ} \mathrm{N}, 96^{\circ} \mathrm{E}$ is nevertheless enigmatic in the context of virtually all other Triassic poles from North America.

\section{ACKNOWLEDGMENTS}

We are grateful to the National Science Foundation (grant ATM93-17227) for financial support. We thank Peter LeTourneau for assistance in field work and for useful discussions of the results, Gilberto Mello for paleomagnetic laboratory work, and C. H. Gover and the Virginia Solite Corporation for giving us free access to the quarries and Cascade Creek. Constructive comments on the manuscript by Bulletin reviewers (Dave Symons and Ken Verosub) and the Associate Editor (Doug Elmore) are also appreciated.

\section{REFERENCES CITED}

Bazard, D. R., and Butler, R. F., 1991, Paleomagnetism of the Chinle an Kayenta Formations, New Mexico and Arizona: Journal of Geophysical Research, v. 96, p. 9847-9871.

Blackett, P. M. S., 1961, Comparison of ancient climates with the ancien latitudes deduced from rock magnetic measurements: Proceedings of the Royal Society of London, v. A263, p. 1-30

Briden, J. C., and Irving, E., 1964, Palaeolatitude spectra of sedimentary palaeoclimatic indicators, in Nairn, A. E. M., ed., Problems in palaeoclimatology: New York, Interscience, p. 199-224, 249-250.

Chase, C. G., Gregory, K. M., and Butler, R. F., 1992, Geological constraints on amounts of Colorado Plateau rotation [abs.]: Eos (Transactions, American Geophysical Union), v. 73, no 14 supplement, p. 95.

Courtillot, V., Besse, J., and Theveniaut, H., 1994, North American Jurassic apparent polar wander: the answer from other continents? Physics of the Earth and Planetary Interiors, v. 82, p. 87-104

Crowley, T. J., 1994, Pangean climates: Geological Society of Americ Special Paper 288, p. 25-39

Ekstrand, E. J., and Butler, R. F., 1989, Paleomagnetism of the Moenave Formation: Implications for the Mesozoic North American apparent polar wander path: Geology, v. 17, p. 245-248.

Froelich, A. J., and Olsen, P. E., 1984, Newark Supergroup, a revision of the Newark group in eastern North America: U.S. Geological Survey Bulletin 1537, p. A55-A58.

Hagstrum, J. T., 1993, North American Jurassic APW: The curren dilemma: Eos (Transactions, American Geophysical Union), v. 74 p. $65,68-69$

Hamilton, W., 1981, Plate-tectonic mechanism of Laramide deformation: Contributions in Geology, University of Wyoming, v. 19, p. 87-92.

Hamilton, W. 1988, Tectonic setting and variations with depth of some Cretaceous and Cenozoic structural and magnetic systems of the western United States, in Ernst, W. G., ed., Metamorphism and crustal evolution of the western United States: Englewood Cliffs, New Jersey, Prentice-Hall, Rubey Volume VII, p. 1-40.

Hubert, J. F., and Mertz, K. A., 1980, Eolian dune field of Late Triassic age, Fundy Basin, Nova Scotia: Geology, v. 8, p. 516-519.

Kent, D. V., and Witte, W. K., 1993, Slow apparent polar wander fo North America in the Late Triassic and large Colorado Plateau rotation: Tectonics, v. 12, p. 291-300

Kent, D. V., Olsen, P. E., and Witte, W. K., 1995, Late Triassic-earlies Jurassic geomagnetic polarity sequence and paleolatitudes from drill cores in the Newark rift basin, eastern North America: Journal of Geophysical Research, v. 100, p. 14965-14998.

Kirschvink, J. L., 1980, The least-squares line and plane and the analysis of palaeomagnetic data: Geophysical Journal of the Royal Astronomical Society, v. 62, p. 699-718.

Kodama, K. P., and Mowery, A., 1994, Paleomagnetism of the Sassamansville diabase, Newark basin, southeastern Pennsylvania:
Support for Middle Jurassic high-latitude paleopoles for North America: Geological Society of America Bulletin, v. 106, p. 952-961.

Kodama, K. P., Hedlund, C., Gosse, J., and Strasser, J., 1994a, Rotated paleomagnetic poles from the Sassamansville syncline, Newark basin, southeastern Pennsylvania: Journal of Geophysical Research, v. 99 , p. 4643-4653.

Kodama, K. P., Cioppa, M. T., Sherwood, E., and Warnock, A. C., 1994b, Paleomagnetism of baked sedimentary rocks in the Newark and Culpeper basins: Evidence for the J1 cusp and significant Late Triassic apparent polar wander from the Mesozoic basins of North America: Tectonics, v. 13, p. 917-928.

Lindholm, R. C., 1978, Triassic-Jurassic faulting in eastern North America-A model based on pre-Triassic structures: Geology, v. 6 , p. 365-368.

Lowrie, W., 1990, Identification of ferromagnetic minerals in a rock by coercivity and unblocking temperature properties: Geophysical Research Letters, v. 17, p. 159-162.

Lucas, S. G., Steiner, M. B., Huber, P., and Hunt, A. P., 1993, Magnetostratigraphy and paleomagnetic poles from Late Triassic-earliest Jurassic strata of the Newark basin: Discussion: Geological Society of America Bulletin, v. 105, p. 1260-1261

McFadden, P. L., and McElhinny, M. W., 1990, Classification of the reversal test in palaeomagnetism: Geophysical Journal International, v. 103 , p. $725-729$.

McIntosh, W. C., Hargraves, R. B., and West, C. L., 1985, Paleomagnetism and oxide mineralogy of upper Triassic to lower Jurassic red beds and basalts in the Newark Basin: Geological Society of America Bulletin, v. 96, p. 463-480

Meyertons, C. T., 1963, Triassic formations of the Danville Basin: Virginia Division of Mineral Resources Report of Investigations 6, p. 65

Molina-Garza, R. S., Geissman, J. W., Van der Voo, R., Lucas, S. G., and Hayden, S. N., 1991, Paleomagnetism of the Moenkopi and Chinle Formations in central New Mexico: Implications for the North American apparent polar wander path and Triassic magnetostratigraphy: Journal of Geophysical Research, v. 96, p. 14239-14262.

Molina-Garza, R. S., Geissman, J. W., and Van der Voo, R., 1995, Paleomagnetism of the Dockum Group (Upper Triassic), northwest Texas: Further evidence for the J1-cusp in the North America apparent polar wander path and implications for rate of Triassic apparent polar wander and Colorado Plateau rotation: Tectonics, varent polar wan 14 , p. $979-993$.

Olsen, P. E., 1978, On the use of the term Newark for the Triassic and Early Jurassic rocks of eastern North America: Newsletters in Stratigraphy, 7, 90-95.

Olsen, P. E., and Gore, P. J. W., 1989, Tectonic, depositional, and paleoecological history of early Mesozoic rift basins, eastern North America: Washington, D.C., International Geological Congress, 28th, Field Trip Guidebook T351, p. 174.

Olsen, P. E., and Kent, D. V., 1996, Milankovitch climate forcing in the tropics of Pangea during the Late Triassic: Palaeogeography, Palaeoclimatology, Palaeoecology, v. 122, p. 1-26.

Olsen, P. E., McCune, A. R., and Thomson, K. S., 1982, Correlation of the early Mesozoic Newark Supergroup by vertebrates, principally fishes: American Journal of Science, v. 282, 1-44.

Olsen, P., Kent, D. V., Cornet, B., Witte, W. K., and Schlische, R. W., 1996, High-resolution stratigraphy of the Newark rift basin (early Mesozoic, eastern North America): Geological Society of America Bulletin, v. 108, p. 40-77.

Parrish, J. T., Ziegler, A. M., and Scotese, C. R., 1982, Rainfall patterns and the distribution of coals and evaporites in the Mesozoic and Cenozoic: Palaeogeography, Palaeoclimatology, Palaeoecology, v. 40 , p. $67-101$.

Ratcliffe, N. M., Burton, W. C., D'Angelo, R. M., and Costain, J. K. 1986, Low-angle extensional faulting, reactivated mylonites, and seismic reflection geometry of the Newark basin margin in eastern Pennsylvania: Geology, v. 14, p. 766-770.

Reeve, S. C., and Helsley, C. E., 1972, Magnetic reversal sequence in the upper portion of the Chinle Formation, Montoya, New Mexico Geological Society of America Bulletin, v. 83, p. 3795-3812.

Robbins, E. I., and Traverse, A., 1980, Degraded palynomorphs from the Dan River (North Carolina)—Danville (Virginia) basin, in Price, $\mathrm{V}$, et al, eds., Geological investigations of Piedmont and Triassic rocks, central North Carolina and Virginia: Carolina Geological Society Field Trip Guidebook, section B, no. 10, 11 p.

Robbins, E. I., Wilkes, G. P., and Textoris, D. A., 1988, Coal deposits of the Newark rift system, in Manspeizer, W., ed., Triassic-Jurassic rifting: North America and Africa: Amsterdam, Elsevier, p. 649-682.

Smith, W. A., 1987, Paleomagnetic results from a crosscutting system of northwest and north-south trending diabase dikes in the North Carolina Piedmont: Tectonophysics, v. 136, p. 137-150.

Smoot, J. P. 1991, Sedimentary facies and depositional environments of early Mesozoic Newark Supergroup basins, eastern North America: Palaeogeography, Palaeoclimatology, Palaeoecology, v. 84 p. 369-423.

Steiner, M. B., 1986, Rotation of the Colorado Plateau: Tectonics, v. 5 , p. 649-660.

wanson, M. T., 1986, Preexisting fault control for Mesozoic basin formation in eastern North America: Geology, v. 14, p. 419-422.

Symons, D. T. A., Bormann, R. E., and Jans, R. P. 1989, Paleomagnetism of the Triassic red beds of the lower Fundy Group and Meso- 
zoic tectonism of the Nova Scotia platform, Canada: Tectonophysics, v. 164, p. 13-24.

Thayer, P. A., 1970, Stratigraphy and geology of the Dan River Triassic basin, North Carolina: Southeastern Geology, v. 12, p. 1-31.

Thayer, P. A., Robbins, E. I., and Ziegler, D. G., 1982, Hydrocarbon potential of the Dan River-Danville Triassic basin, North Carolina and Virginia: Geological Society of America Abstracts with Programs, v. 14 , p. 89.

Van Fossen, M. C., and Kent, D. V., 1990, High-latitude paleomagnetic poles from Middle Jurassic plutons and Moat Volcanics in New England and the controversy regarding Jurassic apparent pola wander for North America: Journal of Geophysical Research, v. 95 , p. $17503-17516$.

Witte, W. K., and Kent, D. V., 1989, A middle Carnian to early Norian ( $225 \mathrm{Ma}$ ) paleopole from sediments of the Newark Basin, Pennsylvania: Geological Society of America Bulletin, v. 101, p. 1118-1126.

Witte, W. K., and Kent, D. V., 1990, The paleomagnetism of red beds and basalts of the Hettangian extrusive zone, Newark basin, New Jersey: Journal of Geophysical Research, v. 95, p. 17533-17545. Witte, W. K., and Kent, D. V., 1991, Tectonic implications of a remagnetization event in the Newark basin: Journal of Geophysical Re- search, v. 96, p. 19569-19582.

Witte, W. K., Kent, D. V., and Olsen, P. E., 1991, Magnetostratigraphy and paleomagnetic poles from Late Triassic-earliest Jurassic strata of the Newark Basin: Geological Society of America Bulletin, v. 103 , p. $1648-1662$.

Wu, F., and Van der Voo, R., 1988, Paleomagnetism of Middle-Late Triassic plutons in southern Maine: Tectonophysics, v. 156, p. 51-58.

MANUSCRIPT ReCEIVED By THE SOCIETY APRIL 15, 1996

MANUSCRIPT ACCEPTED AUGUST 12, 1996

LAMONT-DOHERTY EARTH OBSERVATORY CONTRIBUTION 5575 